\title{
No Country for Old Men: a search for masculinity in later life
}

\author{
By BENJAMIN SAXTON* E THOMAS R. COLE ${ }^{\dagger}$
}

\begin{abstract}
As several recent studies have shown, contemporary scholarship on masculinity in later life is beset with significant limitations that mirror social and cultural aspects of the very subject that it is meant to study. Reflecting the culture at large, studies of masculinity have presupposed an unspoken, static image of midlife men as the criterion for manhood. This essay reads the protagonist of No Country for Old Men, Sheriff Ed Tom Bell, in the context of masculinity studies, age studies, and the evolution of the American Western. Both Cormac Mcarthy's novel and the Coen brothers' film adaptation will be addressed. We argue that, as a man who becomes deprived of the traditional props of ageless male identity, Bell offers an unexpected and intriguing instance of the search for late-life masculine identity. By the end of No Country for Old Men, Bell has departed from the traditional masculinity scripts of the American Western. He is an aging, ineffectual cowboy who has retired, renounced the violence that sustained his male dominance, and lost the moral certainty that ensured his identity. Bell is no longer certain of who he is - which leaves him free to find out what it might mean to be an old man.
\end{abstract}

* Benjamin Saxton, Department of English, Rice University, Houston, TX, USA

$\dagger$ Thomas R. Cole, The McGovern Center for Humanities and Ethics, Houston, TX, USA 
International Journal of Ageing and Later Life

Keywords: aging, American film, identity, "the Western", masculinity, Cormac McCarthy, No Country for Old Men.

\section{Introduction}

Gerontology and age-related studies have tended to omit analyses of older men, focusing instead on older women or ungendered portraits of aging. As a result, the field has contributed to the cultural "invisibility" of older men and the inverse correlation between masculinity and aging (Thompson 2006). Only recently have scholars begun to point out the problem and call for alternatives (see, for instance, Calasanti 2004; SpectorMersel 2006; Swinnen 2011; Thompson 2006; Van den Hoonaard 2007). As Gabriela Spector-Mersel (2006) has noted, contemporary society offers older men an incomplete script for performing masculinity: "While in relation to early and middle adulthood we find clear models of dignified masculinity, these become vague, even non-existent, when referring to later life ... Western masculinity scripts are not designed for elderly men, and thus are concluded somewhere before 'old age'"' (73). Older men thus lack an alternative to midlife masculine ideals, depriving them of guidelines for being a "real" man and limiting their ability to fashion effective and culturally respectable identities.

This essay suggests that, by relinquishing the masculine expectations of the heroic lawman, Sheriff Ed Tom Bell offers a new script for older men in the struggle for a viable masculinity. As the lawman of Terrell County, Texas, for over 30 years, Bell has anchored his life in traditional values and common sense. But with the arrival of Anton Chigurh - a relentlessly violent, amoral mercenary - Bell witnesses social turmoil and senseless violence that shatter his sense of purpose and force him to reflect upon the ultimate meaning of his life. In our opinion, No Country for Old Men is not only a story about violence and greed; it is also about morality and the search for a coherent and socially viable identity for old men in contemporary society. Our discussion will focus on these concerns within the context of the American Western, a genre in which the cowboy hero offers an exaggerated instance of what it means to "be a man". In contrast to his heroic counterparts, we suggest that Bell represents a unique 
character: an aging cowboy whose inchoate search for an alternative form of aging masculinity moves toward nonviolence, dialog, and community.

To appreciate Bell's distinctiveness within the genre, this essay will set him alongside two archetypal heroes of the Western: the Lone Ranger and Clint Eastwood's William Munny. While neither figure must be paired with Bell, they both stand as useful counterpoints for tracing the historical transition from the ageless to the aging cowboy in American cinema. Traditionally, the cowboy hero (exemplified by the Lone Ranger) has been portrayed as an ageless guarantor of unchanging truth and justice. However, in the last 20 years, American Westerns have evolved to make room for the aging of the heroic cowboy who, in spite of his age, reasserts male dominance through violence. Aging successfully (or, for the fantastical Lone Ranger, not aging at all) remains tied to the performance of youthful masculinity scripts (Spector-Mersel 2006). In contrast, Bell is a convincingly human protagonist who departs from conventional scripts of what it means to "be a man", thereby offering a potentially illuminating model of late-life masculinity.

\section{The Story and the Crisis of Ed Tom Bell}

Thanks to the Coen brothers' film adaptation of Cormac McCarthy's novel, Bell's story has become inseparable in popular imagination from the actor who plays him (Tommy Lee Jones) and the cinematic tradition of the American Western. In considering the novel and the film together, we are faced with a kind of artistic hybrid, or what Rick Wallach (2009) has called "a dialogue between two mediums" (xi). While the film adaptation is faithful in most respects to McCarthy's novel, a key difference that should be mentioned here is Bell's role as a central character. In the novel, the 13 interior monologs feature his extended reflections and clearly delineate Bell as the protagonist. In contrast, although the Coen brothers open and close the film with voiceovers taken from Bell's monologs, most of these ruminations are sacrificed in favor of the faster-paced contest between the two other protagonists, Llewellyn Moss and Anton Chigurh. This essay relies primarily on interior monologs from the novel but also will reference key moments in the film - especially the final scene in which Bell discusses 
International Journal of Ageing and Later Life

his two dreams with his wife, Loretta. In this way, the novel and the film mutually inform and enrich our understanding of Bell. ${ }^{1}$

McCarthy presents Bell's story in two ways, moving between thirdperson narration and Bell's first-person, italicized monologs that preface each chapter. Rather than presenting the action in a straightforward manner, Bell's testimonials are usually further ahead in the chronology of his narrative than the events detailed in the chapters proper. As retrospective reflections on what he has seen, Bell's monologs expose us to the intimate, interior thoughts of a character who otherwise seems as impervious as the vast desert landscape. The oscillating movement of the narrative, which swings between the events of the story and Bell's interpretation of them, illuminates his gradual process of transformation as a man. As we will see, Bell is a dynamic character whose experiences especially those involving Anton Chigurh - lead him to question, and ultimately to leave behind, many of the certainties on which he has based his life.

At the outset of the story, Bell's moral world seems to be intact. He believes in Truth with a capital $\mathrm{T}$ and has no doubts about right and wrong or which side he is on. In short, Bell is the quintessential small-town sheriff: honorable, old-fashioned, and set in his ways. Like many a conservative red-neck - which is how some critics see him (Cremean 2010: 21-31) - Bell retains nostalgia for older times and stubbornly believes that society is getting worse. He notes, for example, that the worst problems teachers faced in the 1930s were talking in the classroom, chewing gum, running in the hallways, or copying someone else's homework. However, in Bell's world of the 1970s and 80s, teachers are dealing with rape, murder, arson, drugs, and suicide. Although he thinks that the society is sliding into moral chaos, Bell's holds to his father's advice: "My Daddy always told me to just do the best you knew how and tell the truth. He said there was nothing to set a man's mind at ease like waking up in the morning and not havin to decide who you were. And if you done somethin wrong just stand up and say

\footnotetext{
${ }^{1}$ For an insightful discussion of the relation between the novel and the film, as well as McCarthy's preoccupation with cinematic modes of representation, see Wallach (2009).
} 
you done it and say you're sorry and get on with it" (McCarthy 2005: 249). Despite these affirmations, we eventually learn that Bell has fallen short of these standards, which causes him to reassess his identity as a man.

The man who throws Bell's life into uncertainty, Anton Chigurh, appears from the start as a model of ruthlessness and efficiency. He methodically pursues Llewellyn Moss, a young welder who, on a hunting trip in the desert, stumbles upon a botched drug deal and a briefcase filled with just over two million dollars. Moss picks up the briefcase, takes it back to his trailer, and plans to make a new life with his wife, Carla Jean. As Chigurh hunts Moss and the money, Bell helplessly trails the action and ponders the implications of their bloody conflict. By the end of the plot, Bell is overwhelmed. Chigurh has escaped with the money. Moss and his wife are dead. The peace in Terrell County has been shattered. Bitter and bewildered, Bell retires from his post as sheriff, no longer certain of who he is or where he fits in the world. After serving his country for 30 years and following traditional codes and values, he finds himself in a position of impotence, disrespect, and confusion. Bell's unreflective moralism, his tepid faith, his stubborn belief in the "older times", and the men who lived during them - all of these consolations have proven to be worthless when Bell needed them the most.

The title of McCarthy's novel alludes to William Butler Yeats's poem "Sailing to Byzantium", which was written when Yeats himself was, like Bell, in his early sixties. Just as Yeats's old man seeks unchanging spiritual and artistic values in the holy city of Byzantium (Yeats 1928: 102), so too does Bell yearn for a timeless moral order. For Bell, this "country" is located in the timeless plains and mountains of West Texas in a mythical era when strong, white men enforced a clear, unquestioned morality. What sort of man embodied the "older time" that Bell yearns for? The fictional star of this mythical world was another Texan and perhaps the most widely known and beloved figure of $20^{\text {th }}$ century American popular culture, that ageless hero, the Lone Ranger. As we will see, the Lone Ranger and the genre of the Western contain a "script" that concludes in middle age, thereby confirming SpectorMersel's (2006) view of hegemonic masculinity scripts as "never-aging stories". 
International Journal of Ageing and Later Life

\section{From Byzantium to West Texas: The Lone Ranger Rides Again}

The Lone Ranger was written as a thrilling tale of morality of the Old West for children and their parents of the Great Depression. As a masked vigilante who operated outside an ineffectual government - but who also had the best interest of the public in mind - the character attracted listeners to the original 1933 radio show "The Lone Ranger" (Hoppenstand 2008). In short order, Superman, Batman, Green Arrow, Sergeant Preston of the Yukon, Green Hornet, and Flash Gordon also swooped onto the radio waves and into comic books - ageless, white, male superheroes ever ready to defend truth, justice, and the American Way (Dorfman 1983). What separated the Lone Ranger from these and other characters was his status as the quintessential hero of the American Western. The Western, as John Cawelti has shown in his classic study The Six-Gun Mystique (1971), follows an archetypal formula: it takes place near the frontier at a point in history when social order and anarchy are in tension, and involves some form of pursuit. The genre of the Western thus encapsulated and gave form to idealized notions of the American West as a site of adventure and innocence. The Lone Ranger rode into town on a white stallion, defeated his enemies with a few well-timed silver bullets (always fired in self-defense), and road off in a cloud of dust. He was a white man who defended "middle-class institutions of marriage, home and womanhood" (Horton 1974: 570-578), showed respect to Indians, and lived by his famous Creed. ${ }^{2}$

\footnotetext{
${ }^{2}$ I believe that to have a friend, a man must be one. That all men are created equal and that everyone has within himself the power to make this a better world. That God put the firewood there but that every man must gather and light it himself.

In being prepared physically, mentally, and morally to fight when necessary for that which is right.

That a man should make the most of what equipment he has.

That this government, of the people, by the people and for the people shall live always.

That men should live by the rule of what is best for the greatest number. That sooner or later ... somewhere ... somehow...
} 
The radio show "The Lone Ranger", which eventually ran for over 2,500 episodes, was followed by a comic book series, 18 novels, and three feature-length films. ${ }^{3}$ As his popularity soared during the mid- $20^{\text {th }}$ century, the image of the noble, manly Lone Ranger remained essentially unchanged. The crucial point here is that the traditional cultural scripts that the Lone Ranger epitomized - power, retributive violence, physicality - rely on the performance of youthful masculinity. SpectorMersel (2006), for instance, argues that "as a result of the ungendered image attributed to older persons, and the construction of older men as an invisible, paradoxical, and unmasculine social category, Western hegemonic masculinity scripts are concluded at middle age. The absence of cultural guidelines for being both a 'true' man and an aging person constitutes the context within which contemporary older men struggle to build acceptable identities" (69). Rather than challenge ageism, this construction reinforces age inequality by defining prosperity in old age in terms of younger experiences (or in relation to one's younger self). In the Lone Ranger franchise, the problem of an older, ineffectual hero was "solved" by making him ageless. As a literally "never-aging" man, to use Spector-Mersel's phrase (2006: 67), the iconic hero continued to save the day, performing the hegemonic masculinity script of middle age.

Even if the Lone Ranger never grew old, the tension between ageless heroism and aging surfaced in the real-life drama between Clayton Moore, the actor who played the Lone Ranger from 1949 to 1951 and from 1954 to 1957, and Jack Wrather, the television show's creator. After the show went off the air, Moore worked in commercials, at country fairs, and made other public appearances (always in costume) for many years. Through his offscreen performances, Moore unmasked the fantasy at the heart of the franchise: the fact that, for 30 years, its hero never grew old. Wrather, who

we must settle with the world and make payment for what we have taken.

That all things change but truth, and that truth alone, lives on forever.

In my Creator, my country, my fellow man. (Hoppenstand 2008)

${ }^{3}$ The three films are The Legend of the Lone Ranger (1952), which existed as a compilation of three television episodes; Warner Brothers' The Lone Ranger (1956); and United Artists' The Lone Ranger and the Lost City of Gold (1958). 
International Journal of Ageing and Later Life

was planning a new movie version with a fresh young hero, wanted to separate public perception of the 65-year-old Moore from his younger replacement and obtained a court order forcing Moore to stop making public appearances as the Lone Ranger (Lawrence 2009: 87). Moore countersued, substituted similar wrap-around sunglasses for the mask, and continued his public appearances. He eventually won the countersuit that permitted him to appear in full costume, which he did until his death in 1999. Today, although the allure of the Lone Ranger remains strong in some cultural quarters and film studios, efforts to revitalize the franchise have been largely unsuccessful. ${ }^{4}$ In its place, a new image of the aging cowboy has found its way into the Western.

\section{"Yes, We Still Can": The Aging Cowboy in American Cinema}

Beyond the rolling plains, bawdy saloons, hostile Indians, and other iconic images of the genre, perhaps the most distinctive feature of the classic Western film is the model of masculinity at its core (Chivers 2011). "Westerns insist on this point", writes Jane Tompkins (1992), "by emphasizing the importance of manhood as an ideal. It is not one ideal among many, it is the ideal, certainly the only one worth dying for. It doesn't matter whether a man is a sheriff or an outlaw, a rustler or a rancher, a cattleman or a sheepherder, a miner or a gambler. What matters is that he be a man" (17-18). Much of what it took to "be a man", as Tompkins and others have noted, involved the aggressive and often violent assertion of white male privilege and dominance - over women, over ethnic and sexual minorities (male or female), over animals, and over the land (Peterson 2011: 74-88). Indeed, when we talk about Westerns, whether they are set in the Old West or the New, questions of masculinity

\footnotetext{
${ }^{4}$ The film The Legend of the Lone Ranger (1981) was a critical and financial disappointment. The two-hour television pilot "The Lone Ranger" (2003), which follows the exploits of the character before he became a legend, was similarly a commercial failure (Lawrence 2009: 80). A film remake starring Johnny Depp who plays an edgier Tonto rather than the Lone Ranger - is in the works. Following F. Scott Fitzgerald, there may be no "second act" in the American life of the ageless Lone Ranger. He may be gone for good, along with the idealized fictional world he was meant to instantiate.
} 
are central and unavoidable; the genre is perhaps the ultimate venue for the display of male power in conflict with both the wilderness and the bad guy.

But what about men who no longer enjoy the physical strength they once held? Who no longer are able to dominate villains through sheer strength and quick reflexes? In an aging society in which some of American cinema's most beloved male actors are growing old, these issues are no longer banished from the silver screen, as they were during the heyday of the Lone Ranger. In the last 20 years, Hollywood has given birth to a new kind of hero, an aging hero whose waning physicality and strength becomes the stimulus for the reassertion of the desired midlife masculinity in later life. In her recent study, The Silvering Screen (2011), Sally Chivers examines a number of contemporary films in which the role of the older male figure is recast from a man whose masculinity is thought to be fading to a man whose masculinity is exaggerated and compensatory. She argues that "enormous effort is made to shore up each male star's increasingly fragile sense of virility at the expense of others, usually women dismissively treated as potential or rejected sexual objects and racialized men easily killed off" (2011: 102). Many of these films, from Harrison Ford's Indiana Jones and the Kingdom of the Crystal Skull (2008) to Sylvester Stallone's The Expendables (2010), suggest that, in spite of real signs of physical decline, aging men need not relinquish any of their power or their dominance. In the American Western, which foregrounds fantasies of power, omnipotence, and control, this struggle is especially prominent.

Clint Eastwood's Unforgiven (1992) offers a paradigmatic case of an older man who follows the hegemonic masculinity script of middle age. The film, which stars Eastwood during his early sixties, presents a model of masculinity in which aging physicality is compensated by means of "astonishing if apparently justified violence" (Chivers 2011: 112). His character William Munny is a legendary, murderous villain who has become a family man and mended his ways thanks to his loving wife who is recently deceased. As a lonely pig farmer mired in poverty, Munny's body is beginning to fail him. He is first seen rolling around in the mud chasing his pigs, consistently unsuccessful in his efforts to catch them. Fetching his gun, he fails to hit the mark a single time during target 
International Journal of Ageing and Later Life

practice, and has even more trouble mounting his horse. The Schofield Kid, an aspiring gunslinger sent to find Munny, comments, "You don't look no meaner-than-hell cold-blooded damn killer" (Eastwood 1992). Munny's comical, bumbling image is further underscored by the actor Eastwood himself, whose previous, younger cowboy roles - A Fistful of Dollars (1964), The Good, the Bad, and the Ugly (1966), and Pale Rider (1985), among others - epitomize the physically powerful, bad-boy hero. ${ }^{5}$

From the start, then, Munny seems resigned to his fate as an ex-outlaw, widower, father of two, pigpen owner, and over-the-hill cowboy. However, soon enough, Munny is drawn against his will to avenge his friend Ned Logan (played by Morgan Freeman) who is brutally whipped to death by the sheriff, Little Bill. With the plot established of the reluctant, wifeless hero thrust back into the fray, Munny embarks on the flurry of retributive violent acts which reinforce his masculinity. The violence culminates in a gripping climax in which Munny guns down the inhabitants of the local saloon, including the corrupt sheriff Little Bill, by himself. "Eastwood's Munny", argues Chivers (2011), "proves his ongoing purchase of power by annihilating his enemies through no real choice of his own, having been drawn back into violence in order to make money for his children, fighting on the side of right even if he does so against the law. He manages to appear simultaneously helpless and powerful, but always a 'man'"' (113). Thanks largely to Eastwood's Munny, a host of aging cowboys have continued to roam the Hollywood countryside, their masculinity reinforced with a smoking shotgun.

What is significant about Ed Tom Bell is the way in which he stands apart from William Munny. ${ }^{6}$ The process by which Munny's masculinity is preserved in Unforgiven - through violence and racial sacrifice - is entirely absent in No Country for Old Men. There are no rejected women or racialized men who are sacrificed to reaffirm Bell's status as a patriarchal,

\footnotetext{
${ }^{5}$ For a treatment of Eastwood's continual engagement with questions of masculinity (especially as a director), see Cornell (2009).

${ }^{6}$ Like Eastwood, whose previous cowboy characters ooze masculinity, Tommy Lee Jones, who plays Bell in the film, also has a long history of hyper-masculine Western roles. His role as the laconic, steadfast Woodrow Call in Lonesome Dove (1989) is perhaps best known. Others relevant roles include The Three Burials of Melquiades Estrada (2005), In the Valley of Elah (2007), and The Fugitive (1993).
} 
white, sexy, strong man. Bell has lived in a long (if imperfect) marriage with his wife, Loretta. However, most importantly, he is not impelled forward by avenging violence, as Munny is, but through renunciation. In her insightful discussion of models of masculinity in No Country, Stacy Peebles (2009) argues that the novel in general and Bell in particular present us with "an alternative mode of engaging with the world, one that doesn't rely on the need to take control with the use of cleverness, stubbornness, rationality, tradition, or lethal force. Instead, this alternative practice is based on renunciation and the surrender to those forces that are beyond one's control rather than in service of it" (125). While Peebles rightly links Bell to this revised model of masculinity - indeed, she is one of the few critics to discuss it - she does not mention the ways in which Bell's experience of aging contributes to this process. In our opinion, it is precisely because McCarthy and the Coen brothers present Bell as a believably aging man that his character can offer a revised masculinity script.

\title{
From Certainty to Doubt: Bell's Journey
}

\begin{abstract}
I always thought I could at least someway put things right and I guess I just dont feel that way no more ... I'm bein asked to stand for something that I dont have the same belief in it I once did .... Now I've seen it held to the light... . I've been forced look at it again and forced to look at myself. For better or worse I do not know .... I never had them sorts of doubts before. (McCarthy 2005: 306)
\end{abstract}

These grim words, spoken at the end of the plot, contrast sharply with the facile pronouncements that Bell once made about virtue, integrity, and right and wrong. It is a powerful admission. To a large extent, the agent of Bell's transformation is Chigurh, a man who turns out to be not only a killer but also a philosopher. "Tell me something," he says to a competing mercenary, Carson Wells, "If the rule you followed led you to this of what use was the rule?" (McCarthy 2005: 175). As Jay Ellis (2011) has noted, Chigurh functions as a kind of "Socratic figure" who intends to help his victims comprehend the significance of their past actions (96). His question to Wells surely applies to Bell as well: if tradition and common sense do 
International Journal of Ageing and Later Life

not work as the "rule" for governing one's life, then of what use is it? With no clear answer in sight, Bell is left with only his doubts.

How should he respond? With more violence to avenge the deaths of Moss, Carla Jean, his deputy, and the innocent civilians left in Chigurh's wake? Bell makes a critical decision: he will not "put his soul at hazard" by pursuing Chigurh (McCarthy 2005: 4). Unlike the Lone Ranger or Munny, Bell walks away; he "quits". On Bell's last day at work,

he walked out of the courthouse for the last time. He walked down the steps and out the back door and got in his truck and sat there. He couldnt name the feeling. It was sadness but it was something else besides. And the something else besides was what had him sitting there instead of starting the truck. He'd felt like this before but not in a long time and when he said that, then he knew what it was. It was defeat. It was being beaten. More bitter to him than death. You need to get over that, he said. Then he started the truck. (McCarthy 2005: 306)

Not surprisingly, most critics consider Bell a failure, albeit a good man and a sympathetic failure. According to Peebles (2004), the end of the novel "sounds a distinct note of defeat for its protagonist and intermittent narrator, Sanderson Sheriff Ed Tom Bell ... He quits - though not without reason" (29). From this perspective, Bell not only fails to catch Chigurh but also fails to "be a man", to live up to the masculine expectations of a sheriff and a productive member of society. In this way, critics unwittingly rely upon a midlife image of masculinity rather than being open to possible masculinity scripts of later life.

In our view, Bell's feeling of defeat is not, in the end, a failure. It is the beginning of a transformation that leads not to superpowers but rather to humility and uncertainty. As David Cremean (2010) puts it, "Bell has examined his old certitudes and found them lacking, recognized them to be at heart but mere excuses. He is now unconcerned with what others think, has moved beyond thinking and acting the way he was expected to" (28). He has, in other words, moved beyond the hegemonic masculinity script of middle age and seeks to redefine its meaning for himself.

Interestingly, McCarthy suggests in the text itself that Bell's personal growth will require more than interior monolog. Monolog, as we learn from Mikhail Bakhtin (1984), fails to acknowledge the equal rights of another's consciousness by treating its own discourse as the final word (292). A number of scholars, most notably Judith Butler (1990), have noted 
the perennial association in Western culture of monologism with masculinity and dialogism with femininity (1990). For most of his life, Bell, playing the part of the taciturn cowboy, gives in to the temptation to shut out other voices. He is, as Bakhtin (1984) puts it, "deaf to the other's response" (292). Bell recalls, for example, meeting a woman in Corpus Christi who worried that her daughter would one day be denied the right to have an abortion. "Well mam", he replies,

\footnotetext{
I don't think you got any worries about the way the country is headed. The way I see it going I don't have much doubt but what she'll be able to have an abortion. I'm goin to say that not only will she be able to have an abortion, she'll be able to have you put to sleep. Which pretty much ended the conversation. (McCarthy 2005: 117)
}

The way in which Bell recalls the woman's insistent talking - "she kept on, kept on" - suggests that her point of view is a mere annoyance. Bell rules out in advance the possibility that the woman's perspective could change any of his own thinking. He also refuses to discuss those things that are most troubling to him: his daughter ("We lost a girl but I wont talk about that") and his military background ("I wont talk about the war neither") (McCarthy 2005: 90, 195). For much of the novel, Bell conforms to a kind of "monologic masculinity", in Hugh Campbell's (2006) words, that "limits the range of topics deemed appropriate for men and women to discuss, regulates a specific definition of what constitutes work and success, and recognizes precise boundaries of manhood" (28). But after the transformative and traumatic events that he witnesses - when his views are "held to the light" - Bell realizes that his own perspective is insufficient to account for what he has seen, which opens him to a different kind of conversation. Bell embraces a more flexible, alternative understanding of what it means to be a man - a kind of "dialogic masculinity" (Campbell et al. 2006: 28) - that leads him to transformative conversations with strangers, his family, and his wife.

To find answers, Bell goes out of his way to speak with a wide range of people: at least two men on death row, Moss's father, Carla Jean, and his uncle Ellis. On the one hand, this search for dialog is quite literal, as he drives along the West Texas roads in his weathered police cruiser. On the other, it is a metaphorical journey into Bell's consciousness, where he grapples with himself, past and present, and questions his role in a society 
International Journal of Ageing and Later Life

where, it seems, he no longer has a home. Perhaps the most important moment of Bell's transformation occurs when he visits his uncle Ellis, a man presumably in his eighties, who was shot while working as a deputy and lives in a wheel chair on some old, isolated ranch. The scene takes place directly after the most harrowing murder in the novel - Carla Jean's - so that questions of death, morality, and justice are foremost in Bell's (and the reader's) mind. ${ }^{7}$ Bell finds Ellis sitting alone, grizzled and stoic, in his cat-filled shack. "I got to say you look older", Ellis says when Bell walks in (McCarthy 2005: 264). "I am older", Bell responds, thus setting the stage for the conversation that he needs to have (McCarthy 2005: 264).

A number of details - the dusty road leading to Ellis's solitary home, the cluttered kitchen filled with dirty dishes and week-old coffee, and the tired, unhurried pace of their conversation - reveal a life filled with idling memories and no remaining active purpose. After initial bantering, the tone eases to a quiet vulnerability, a genuine openness and authenticity that are missing elsewhere in the story. In the film, agony and sadness are beautifully etched on Tommy Lee Jones's fleshy, expressive face. The tone of their conversation is pensive and retrospective, with both men conscious of the fact that, having lived most of their lives, the time has come for reflection and, perhaps, contrition. As they talk, several core questions come into focus. First, the use of violence: the man who shot Ellis and left him in a wheel chair has died in Angola Prison. Bell asks Ellis what he would have done if the man had been released. "Nothing, there wouldn't be no point to it", Ellis responds (Coen 2007). "All the time you spend trying to get back what's been took from you more's going out the door. After a while you just have to try and get a tourniquet on it" (Coen 2007). Ellis suggests that mastery and retributive violence - the kind that Munny and other cowboy heroes engage in - is no more than a misguided illusion. One should simply move on and, as it were, "get a tourniquet" on one's losses. Bell is surprised by this response, which seems to confirm his own decision not to pursue Chigurh.

\footnotetext{
${ }^{7}$ In the film, the Coen brothers chose to insert the scene directly before Carla Jean's murder, implying that Bell is not yet aware of her death. It is thus Moss's death that weighs most heavily on his mind.
} 
At the same time, Ellis, whom many critics see as the moral center of the novel, ${ }^{8}$ refuses to accept Bell's nostalgia as a fitting attitude toward the "new" problems that he faces. He recounts the story of Uncle Mac, their distant relative who was gunned down in a horrific fashion on his own porch. As he listens to the story, Bell may have been reminded of Moss's demise. Like Uncle Mac, Moss was outnumbered, ambushed by surprise, and shot in a doorway in a thwarted effort to get his shotgun. Whether one lives today or a hundred years ago, "This country will kill you in a heartbeat and still people love it", Ellis says (McCarthy 2005: 271). Ellis rejects the notion that violence is always on the right side of the law: it is far too volatile and capricious to be in sole possession of "the good guys". Following Joan Mellon and others (see also De Boever 2009), one is tempted to relate Ellis's cautionary words to the long, bloody history of America as a whole. As Mellon (2008) puts it, "The stain of imperial domination, first at home at the moment of America's creation, and later in Vietnam and Iraq, has borne an accelerating historical legacy, symbolized by the spreading pool of [Carson] Wells's blood. Anton Chigurh is America's signature future, while Bell and his alter ego Hank Deerfield have found themselves no longer living in the country in which they were born" (31). Ellis is surely correct, then, when he tells Bell that his recent bout with violence "aint nothing new" (Coen 2007). Just as Bell searches for a nonviolent model of masculinity by which to live his life, Ellis's indictment of violence in No Country suggests the need for an alternative to America's recurring history of violence and imperialism.

\section{Renunciation, Retirement, and the Road "On Ahead"}

Bell's conversation with Ellis does not resolve any of his questions. As one of many reflective reminiscences and conversations, it stands as the centerpiece of an ongoing life review (Butler 1963). ${ }^{9}$ Just as importantly, it also shows that Bell is finally willing to confront his doubts and fears

${ }^{8}$ Cremean (2010), Peebles (2009), and Ellis (2011) all see Ellis as an unlikely source of wisdom.

${ }^{9}$ The literature on life review is enormous. Some of it is reviewed in Achenbaum (2013). 
International Journal of Ageing and Later Life

with those closest to him. Indeed, their conversation is ultimately a rehearsal - Ellis calls it a "practice run" (McCarthy 2005: 279) - for the intimate conversation that Bell plans to have with Loretta. "You aim to tell her?" Ellis asks. "Yes sir. I do" (McCarthy 2005: 279). Though the novel leaves Bell's conversation with Loretta to the imagination - Bell talks more to himself (or to the reader) than to his wife - the final scene of the film offers a glimpse of their future together. As the pair sits around the breakfast table, Loretta pours them coffee; Bell looks uncomfortable and out of place. Their discussion foregrounds problems of who he is and how to spend his days. "Maybe I'll go riding", he suggests. "I can't plan your day", she replies (Coen 2007). After suggesting that they go for a ride together, she replies, even more pointedly, "Lord, no, I'm not retired". Unlike her husband, the comment implies, Loretta still has a useful role to fill in the community. Bell keeps trying: "Maybe I'll help out here then", he offers. "Better not", she answers, clearly delineating her role as keeper of the home (Coen 2007). In the end, their relationship will still remain traditionally gendered. Bell will depend on her for every kind of moral and emotional support, and she will love him without any resentment, regret, or reservation. But without the social props and privileges of the cowboy hero, Bell seems consigned to inactivity and confusion.

Is this not the image of a man who has "quit"? Mellon (2008) sums up the common opinion when she describes the final scene of the film: "Sheriff Bell, a broken, idle man, sits at his kitchen table, empty of occupation and usefulness to the community he had served since he was a twenty-five-year-old lawman" (33-37). From this perspective, Bell is overwhelmed in the face of impending retirement and death, which are ultimately the same thing. However, in our opinion, the road "on ahead" is not death but a new phase of life that is filled with uncertainty and promise with Loretta. Critics who dismiss Bell as a failure should consider the courage that it takes him after 30 years to question his most cherished values and to pursue conversations with urgency and honesty. In this respect, as Bell tells his wife his dreams, the narrative act is itself a kind of victory. It is a different kind of breakthrough, to be sure, but it is a crucial one.

When one considers the final scene from this perspective - Bell telling a vital and vulnerable part of himself to Loretta - his final dream takes 
on further significance. In the dream, his father has gone ahead to an undetermined location to prepare a fire, and there is no telling how long it will take to get there. Bell can only follow behind, knowing that he will always arrive a bit too late but knowing, too, that his father has gone ahead to comfort and protect him (McCarthy 2005: 308-309). While critics have tended to interpret the dream in terms of its broader resonances, especially Bell's impending death, ${ }^{10}$ the images might also stand for the uncertain phase of Bell's retirement. Like Yeats's old man, who exists in transit between his homeland and the transcendent city of Byzantium, the final images in No Country are of travel, impermanence, and flux. By declining to reveal Bell's fate, McCarthy situates himself within a modernist tradition that foregrounds the process, or the coming-to-be, of the journey over any final outcome.

From the perspective of masculinity studies, Bell's dream is typical of the incomplete and inchoate scripts for older men. As we have suggested in this essay, Bell stands apart from the heroic violence of the Lone Ranger, William Munny, and other heroes of the American Western. While he cannot offer a solution, Bell's search implies that there may be numerous ways of being an old man - not a one-size-fits-all image to which one must conform. By the novel's end, Bell seems to understand that any new scripts for late-life masculinity must begin and end with self-knowledge. As he puts it: "it's a life's work to see yourself for what you really are and even then you might be wrong" (McCarthy 2005: 295).

\section{Acknowledgments}

This article was presented at the "Theorizing Age" Conference, which was the 7th International Symposium on Cultural Gerontology and also The Inaugural Conference of the European Network in Ageing Studies, held in

\footnotetext{
${ }^{10}$ De Boever (2009), for instance, writes that the governing symbols of the dream, light, and fire, "can easily be read as the light and fire of justice: as the dream of final control that is projected up ahead, with the sheriff's long-dead father protecting it until the sheriff will get there himself, in other words: until the sheriff himself will have died. One does not have to be a psychoanalyst to understand the dream's significance: only in death will the sheriff's work of justice be completed. Final justice is not a part of this world" (143).
} 
International Journal of Ageing and Later Life

Maastricht, 6-9 October, 2011. The authors express their gratitude for the editorial assistance of Aajge Swinnen and Cynthia Port and for the support of Roberta Maierhofer.

\section{Corresponding Author}

Benjamin Saxton, Department of English, Rice University, 1753 West Alabama Street Apt. 3, Houston, TX 77089, USA. Email: saxtonb@ gmail.com

\section{References}

Achenbaum, A. (2013). Robert Butler, M.D.: Visionary of Healthy Aging. New York: Columbia University Press.

Bakhtin, M. (1984). Problems of Dostoevsky's Poetics. M. Holquist (ed.), C. Emerson (trans.). Minneapolis, MN: University of Minnesota Press.

Butler, J. (1990). Gender Trouble: Feminism and the Subversion of Identity. New York: Routledge.

Butler, R. (1963). The life review. Psychiatry 26: 65-76.

Calasanti, T. (2004). Feminist gerontology and old men. Journal of Gerontology: Social Sciences 59(6): 305-314.

Campbell, H., Bell, M. \& Finney, M. (eds.). (2006). Country Boys: Masculinity and the Country Life. University Park: Pennsylvania State University.

Cawelti, J. (1971). The Six-Gun Mystique. Bowling Green, OH: Bowling Green University Press.

Chivers, S. (2011). The Silvering Screen. Toronto: University of Toronto Press.

Coen, J. E. (dir.) (2007). No Country for Old Men. DVD. Miramax Films.

Cornell, D. (2009). Clint Eastwood and Issues of American Masculinity. New York: Fordham.

Cremean, D. (2010). For whom Bell Tolls: Sheriff Bell as spiritual hero. In L. C. King, R. Wallach \& J. Welsh (eds.), No Country for Old Men: From Novel to Film (pp. 21-31). Plymouth: The Scarecrow Press.

De Boever, A. (2009). The politics of retirement: Joel and Ethan Coen's No Country for Old Men after September 11. Image \& Narrative 10(2): 135-149. 
Dorfman, A. (1983). The Empire's Last Clothes. New York: Pantheon.

Eastwood, C. (dir.) (1992). Unforgiven. DVD. Warner Home Video.

Ellis, J. (2011). 'Do you see?' Levels of ellipsis in No Country for Old Men. In S. L. Spurgeon (ed.), Cormac McCarthy: All the Pretty Horses, No Country for Old Men, The Road (pp. 94-116). London: Continuum.

Hoppenstand, G. (2008). The Lone Ranger: Justice Outside the Law. Available on: http://www.npr.org/templates/story/story.php? storyId=18073741 (Accessed: October 2, 2011)

Horton, A. (1974). Ken Kesey, John Updike, and the Lone Ranger. Journal of Popular Culture 8(3): 570-578.

Lawrence, J. S. (2009). The Lone Ranger: Adult legacies of a juvenile western. In P. Rollins \& J. O'Connor (eds.), Hollywood's West: The American Frontier in Film, Television, and History (pp. 81-98). Lexington, KY: University of Kentucky Press.

McCarthy, C. (2005). No Country for Old Men. New York: Random House.

Mellon, J. (2008). Spiraling downward: America in Days of Heaven, In the Valley of Elah, and No Country For Old Men. Film Quarterly 61(3): 33-37.

Peebles, S. (2004). Bean, bell, and the efficacy of Texas Lawmen: 'Old Timers' in No Country for Old Men. The Journal of the American Studies Association of Texas 35: 29-43.

Peebles, S. (2009). 'Hold still': Models of masculinity in No Country for Old Men. In L. C. King, R. Wallach \& J. Welsh (eds.), No Country for Old Men: From Novel to Film (pp. 124-138). Plymouth: The Scarecrow Press.

Peterson, D. (2011). New west or old? Men and masculinity in recent fiction by Western American men. Western American Literature 46(1): $74-88$.

Spector-Mersel, G. (2006). Never-aging stories: Western hegemonic masculinity scripts. Journal of Gender Studies 15(1): 67-82.

Swinnen, A. (2011). Seksualiteit en de crisis van het mannelijke subject op leeftijd in Een tweede jeugd. In A. Swinnen (Ed.), Seksualiteit van ouderen: Een multidisciplinaire benadering (pp. 291-313). Amsterdam: Amsterdam University Press.

Thompson, E. H. (2006). Images of old men's masculinity: Still a man? Sex Roles 55(9): 633-648.

Tompkins, J. (1992). West of Everything: The Inner Life of Westerns. Oxford: Oxford University Press. 
International Journal of Ageing and Later Life

van den Hoonaard, D. K. (2007). Aging and masculinity: A topic whose time has come. Journal of Aging Studies 21(4): 277-280.

Wallach, R. (2009). Dialogues and intertextuality: No Country for Old Men as fictional and cinematic text. In L. C. King, R. Wallach \& J. Welsh (eds.), No Country for Old Men: From Novel to Film (pp. 21-31). Plymouth: The Scarecrow Press.

Yeats, W. B. (1928). Sailing to Byzantium. In M. L. Rosenthal (ed.), Selected Poems and Four Plays of William Butler Yeats (4th ed., pp. 102-103), (1996). New York: Scribner. 